\title{
Social Inequality, Childhood and the Media
}

\subsection{INTRODUCTION}

Our study deals with socially disadvantaged children and adolescents in Austria. Hence, we discuss their life circumstances, their opportunities to participate in society, the process of their socialisation and, in this context, the role of media. To better understand the specific challenges facing them as they grow up in a rich country like Austria, we will initially examine the framing conditions in Austria and in other countries, as well as the relevant analytical concepts. Our topics are the national contexts of inequality, the particular nature of being socially disadvantaged in a rich Western society (particularly the examples of Austria and Germany) and, as a consequence, the inequality gap. We then go on to connect these findings with the concept of mediatization and to outline what our findings mean for academia. In conclusion, we offer an insight into the state of research and will, against this backdrop, set out the concrete aim of our longitudinal study.

\subsection{National Contexts of Inequality}

\subsubsection{Social Disadvantage in Rich Western Societies}

In rich countries, social disadvantage is normally not synonymous with severe poverty or material deprivation on an existential level. But poor

I. Paus-Hasebrink et al., Social Inequality, Childhood and the Media, Transforming Communications - Studies in Cross-Media Research, https://doi.org/10.1007/978-3-030-02653-0_2 
people, or people at risk of poverty or of being marginalised, run the risk of being further pushed to the margins of society due to a lack of opportunities and possibilities for participation. It is children and adolescents who are particularly at risk: in many rich countries, where the percentage of younger people who are poor or at risk of poverty or marginalisation is higher than that in the population at large. However, there are examples, like Austria and Germany, which demonstrate the opposite case, because this relationship is reversed in these two countries (see, for example, Guio, Gordon, \& Marlier, 2017, p. 217; UNICEF, 2016 , p. 2). Nevertheless, even in our specific examples, young people are especially at risk where they are affected by the conditions of their families. Poverty or social disadvantage do not mean material deprivation alone. A lack of financial resources also has a major impact on educational achievement, and thus children's life prospects (for example, access to the labour market). In addition, leisure opportunities, social participation, physical health and well-being are also affected. And in consequence, children from lower-income households tend to be sick more often, not only when they are young but also as adults. This results in a poorer state of health than that displayed by the population at large (cf. SOS Kinderdorf, 2017). These recent findings are specific to Austria and fit in with recent research on social disadvantage (cf. Berka \& Trappel, 2017, pp. 122-124; Bertelsmann Stiftung, 2016; Einböck, Proyer, \& Fenninger, 2015, pp. 14-16; Laubstein, Holz, \& Seddig, 2016, pp. 12-16 and 18-24; Paus-Hasebrink, 2017, pp. 15-17; PausHasebrink \& Bichler, 2008, pp. 17-23; Paus-Hasebrink \& Kulterer, 2014a, pp. 18-24; UNICEF, 2016, p. 2). Further aspects of disadvantage are higher rates of obesity, addiction developing at a younger age, underachievement in education, fewer friends and peers outside the family and smaller personal networks, limited access to cultural events and sports communities, as well as inability to participate in public discourse and problematic patterns of media usage. In more general terms, these facets and categories of social disadvantage can be subsumed under the headings: "Income", "Education", "Health" and "Life satisfaction" (UNICEF, 2016, p. 12). In particular, living a satisfactory life is closely linked to current living conditions, future prospects and opportunities to participate.

There are numerous differing approaches to defining social disadvantage. They include simpler ones only based on formal education and family income, but also the more complex, taking into account 
additional factors. In the last analysis, the design of a particular project will be aligned with research questions and the resources available. However, as far as social disadvantage goes, the national contexts are of prime importance, because specific living conditions have to be seen comparatively across an entire country. In this respect, it is also important to note that poverty or social disadvantage in some regions of Asia, Africa, South America, or even in some countries of Southern and Eastern Europe, is not comparable to being poor or socially disadvantaged in rich Western societies, like Austria or Germany, with their well-developed welfare states. In such countries, social disadvantage is closely linked to a lack of opportunities for participation in society (cf. Berka \& Trappel, 2017, pp. 66-68, 122-124; Paus-Hasebrink, Sinner, \& Prochazka, 2014, p. 2; van Dijk, 2013, p. 35). People risk a sense of being left behind, with children and single parents being particularly vulnerable. Guio et al. (2017, p. 213) have compiled a list of 18 items in order to build a material deprivation "indicator related to the children (aged 1-15 years) population". This list of items is closely linked with the 2009 EU-SILC (EU Survey on Income and Living Conditions) data on material deprivation related to child deprivation (Guio et al., 2017 , p. 210). Beside obvious material items, such as food, clothing and shoes, house heating or the ownership of a car, it includes also farther-reaching needs, such as access to suitable books, a personal place to do homework, leisure activities, opportunities to celebrate and to invite friends and to participate in school activities or trips. Unfortunately, we have to state that, in rich countries too, there is a remarkable percentage $(3-18 \%)$ of deprived "children lacking at least 3 out of 18 items". The value for Austria is $12 \%$ and for Germany 15\% (Guio et al., 2017, p. 217, quotation is bold in original). The percentage of such deprived children is very low for non-poor children in rich countries, but it rockets upward when it comes to poor children: "even the best performing countries (with the exception of Sweden) do not manage to protect income-poor children from material deprivation" (Guio et al., 2017, p. 218). It should be noted that. alongside Belgium and France, Austria is one of the countries facing the most serious inequality between poor and non-poor children, indicating the impact that poverty has on Austrian children's lives.

Based on several studies of childhood, adolescence, poverty and social disadvantage in Germany (AWO-ISS, 2012, 2013; Bertelsmann Stiftung, 2016; Palentien, 2003) and Austria (Einböck et al., 2015), 
but also considering more detailed studies of selected regions (for example, Caritas, 2016), we have to state that poverty and social disadvantage, with their concomitant consequences for the everyday life and the future prospects of the persons concerned, are serious problems in rich countries. Even though there is a positive development (Guio et al., 2017, p. 217), and the poverty rates of children in Austria or Germany are lower than in many other countries, there are some countries doing still better. Norway, for example, is rich, whereas the Czech Republic is less so, yet both countries display a poverty rate among children significantly lower than in Germany and Austria (cf. UNICEF, 2016, p. 4). However, (national) efforts to lower the proportion of young people at risk of poverty or being marginalised are laudable, given that the United Nations Convention on the Rights of the Child stipulates that the goal should be a reduction to $0.0 \%$. In accordance with this, new Sustainable Development Goals (SDGs) for 2030 were adopted by the United Nations in 2015 in order to replace the Millennium Development Goals: Goal 1 is named "End poverty in all its forms everywhere", this includes topic 1.1 "by 2030, eradicate extreme poverty for all people" and topic 1.2 "by 2030, reduce at least by half the proportion of men, women and children of all ages living in poverty in all its dimensions according to national definitions", while goal 10 represents the aim to "reduce inequality within and among countries" (Atkinson, Guio, \& Marlier, 2017, pp. 44-45, emphasis in original). The SDGs are more ambitious than the social inclusion target of the European Union for 2020. But "halving poverty by 2030 should not be beyond the resources of a rich continent" (Atkinson et al., 2017, p. 47).

\subsubsection{The Case of Austria and Germany}

Austria and Germany certainly belong to the wealthiest countries in the European Union and the world at large. We highlight the example of Austria because it is the source of the study presented here. But in addition, we also focus on Germany for several reasons. To begin with, two families moved to different parts of Germany during the study, and one girl was attending school on the other side of the border-the State of Salzburg shares a common EuRegio with parts of the State of Bavaria. But even more important is the fact that Austria and Germany are closely interlinked in many ways, although their national contexts do differ: firstly, they share a common language area (but also with parts of 
Belgium, Denmark, Luxembourg, Italy and Switzerland), which means that their national media systems are interwoven; secondly, they share a long and eventful history; thirdly, they share common cultural values and traditions; fourthly, the scientific communities of both countries are closely linked as well, and research findings concerning Germany are often utilised by Austrian authorities too, because of their lack of national data.

Based on a comparison of the gross domestic product (GDP), Austria is the fourth richest country in the European Union, while Germany is the seventh. However, the individual consumption expenditure of households (goods and services, adjusted for purchasing power) ranks Germany second and Austria third. Unchallenged leader in both rankings is Luxembourg (ORF/APA, 2017). Germany, in particular, is currently characterised by stable growth, high tax revenues and the lowest unemployment rates since 1989 (cf. Eurostat, 2017c, pp. 30-31). That said, the reforms of the German welfare state and labour market, the so-called "Gesetze für moderne Dienstleistungen am Arbeitsmarkt" (Four Laws for Modern Services on the Labour Market), have resulted in a rising number of so-called "working poor" (AWO-ISS, 2012, pp. 6-7) and a growth of inequality. Compared to Germany, economic development in Austria has been lagging behind in recent years (cf. Eurostat, 2017c, pp. 60-61). But the Austrian state's social welfare system is somewhat more comprehensive than that in Germany. Austria has higher pensions, higher unemployment benefits over a longer period, study grants, social housing and family allowances (Statistik Austria, 2017a, pp. 4-6). Such transfer payments reduce the income inequality gap by $39.2 \%$ in Austria, but only by $31.5 \%$ in Germany. By contrast however, the reduction is even greater in the UK, at $48.4 \%$ (UNICEF, 2016, p. 16).

What has come to be called the refugee crisis is another important aspect of the situation in Austria and Germany (see Chapter 6 on socialisation in different contexts). Together with Sweden, Italy, Spain, and Greece, in recent years Germany and Austria have had the greatest problems in dealing with very high numbers of refugees. In addition, both countries are preferred destinations for people called economic migrants and for poor people from South-Eastern countries of the European Union. This situation was one reason behind the favourable electoral results for right-wing parties like the FPÖ in Austria and the AfD in Germany, both of which have tried to capitalise on people's fear of being left behind. Difficult times (see Lange \& Xyländer, 2011), as 
exemplified by the refugee crisis, are challenges for the state and society in general, because people who are already socially disadvantaged are afraid of becoming further marginalised and alienated from the rest of society. But despite the increase in social inequality and the national and regional disparities in the European Union, being poor is not a one-way street in Germany (AWO-ISS, 2013, p. 19). Social advancement or a sustainable improvement of your socio-economic situation are possible. Social disadvantage is often closely linked to a migration background. However, a relevant aspect here is the way poor migrant adolescents tend to deal better with economic problems than poor German non-migrant teenagers, in part because the former are supported by stronger social networks through strong family structures (AWO-ISS, 2012, p. 2). Therefore, it is important to keep in mind that a migration background is not, per se, a reason for social disadvantage. It is much rather the case that relevant contexts have to be taken into account, and a migration background should not be advanced as a simple explanation for lacking participation opportunities or lower formal education.

\subsubsection{The Inequality Gap in Western Societies, and in Austria and in Germany}

Although some findings on Austria and Germany generate a positive image, we should nevertheless remember that all that glitters is not gold. "The gap between rich and poor [is] at its highest level for some three decades in most OECD countries" and all "across the OECD, the risks of poverty have been shifting from the elderly towards youth since the 1980s" (UNICEF, 2016, p. 2). In contrast to the current positive situation, these developments apply to the European Union as a whole, as well as Austria and Germany. We have seen increasing rates of poverty and social exclusion since the mid-1980s in Europe, due to rising unemployment rates, changing ways of living together and reductions in social benefits (Bertelsmann Stiftung, 2016; Palentien, 2003). The unequal distribution of resources and opportunities affects family life (Jokinen \& Kuronen, 2011, p. 45). Socially disadvantaged families have to face and to cope with particular challenges, such as unemployment, often interlinked with health problems, and critical socio-emotional problems (Paus-Hasebrink \& Kulterer, 2014b). However, socially disadvantaged people need and merit the support of society, and children and 
adolescents particularly so, because they are not responsible for the economic circumstances they are facing. "In addition, few dispute that childhood experiences have a profound effect not only on children's current lives, but also on their future opportunities and prospects. Likewise, social and economic disadvantages in early life increase the risk of having lower earnings, lower standards of health and lower skills in adulthood. This in turn can perpetuate disadvantage across generations" (UNICEF, 2016, p. 2).

Today, the child poverty rate (measured as $50 \%$ of the national median household income) is $7.2 \%$ in Germany and 9.6\% Austria. On this measure, Finland (3.7\%), Norway (4.5\%) and Denmark (4.8\%) (UNICEF, 2016, p. 4 ) are the leading countries. In contrast to the UNICEF data, it is more common in the European Union to make use of the indicator, "risk of poverty or marginalisation". This includes those people exhibiting at least one of the following three criteria (see Statistik Austria, 2017b, pp. 80-81): (a) living in a household with a household income of less than $60 \%$ of the national median (2016: $14 \%$ of the population); (b) significant material deprivation (2016: $3 \%$ of the population); (c) people under 60 unemployed or with very low earnings (2016: 8\%). According to this, the proportion of people at risk of poverty or of being marginalised in Austria decreased from 20.6\% in 2008 to $18 \%$ in 2016 (Statistik Austria, 2017a, p. 2; see Eurostat, 2017a, pp. 30-31, for a comparison between EU-28, Euro-area 19, EFTA and EU candidates). Compared to this percentage for the whole population, the respective percentage for young people up to 19 was $20.0 \%$ in 2016 (see Table 2.1 ). While these figures, taken in isolation, do not indicate a particular risk of poverty threatening children and adolescents, the results become more problematic if we take a closer look at family structures. The risk of poverty or being marginalised is considerably higher for single-parent families: $38 \%$. In addition, the number

Table 2.1 Risk of poverty or being marginalised in different groups in Austria 2016

\begin{tabular}{lc} 
Total population & $18 \%$ \\
Children (up to 19 years) & $20 \%$ \\
Single parent families & $38 \%$ \\
Multiperson households +1 child & $12 \%$ \\
Multiperson households +2 children & $13 \%$ \\
Multiperson households +3 or more children & $31 \%$ \\
\hline
\end{tabular}

Statistik Austria (2017b, pp. 80-81) 
of children in a family is also linked with a higher risk of poverty or being marginalised: for multiperson households with at least three children, the risk of poverty or being marginalised is $31 \%$ (Statistik Austria, 2017b, pp. 80-81). Furthermore, long-term unemployment and low formal education are relevant factors behind poverty in Austria.

Across the whole population in Germany, the proportion of people at risk of poverty or being marginalised turns out to be a bit higher than in Austria, at 20\%. The risk for younger people (under 18 in Germany) is slightly lower than in Austria (19\%) (Statistisches Bundesamt, 2017a). It is worth noting that the situation is not uniform throughout Germany; there are notable differences between the German Länder (Federal States) and in particular between Eastern and Western areas of the country (see Statistisches Bundesamt, 2017b). In addition, single-parent households are particularly at risk in Germany: the quota of such families at risk of poverty or being marginalised was 40\% in 2014 (Statistisches Bundesamt, 2016, pp. 173 and 176). And just as in Austria, people unemployed long-term and people with a low level of education are also particularly at risk.

These figures are in line with the results of the UNICEF report on inequality in children's well-being in rich countries. Austria and Germany both belong to a group of countries in which the relative gap of income inequality remained more or less stable in the period of 2008-2013: Austria reports a reduction of the relative gap in income inequality by $0.8 \%$, while Germany reports a small increase of $0.5 \%$ (UNICEF, 2016, p. 15). Having this in mind, we should nevertheless emphasise: "Income gaps have widened in the majority of rich countries" (UNICEF, 2016, p. 14; quotation is bold in original). However, developments in Austria and Germany actually appear more favourable if we look back to the middle of the first decade of the twenty-first century, when the long-term study on which this book is based started (see also Eurostat, 2017 b, p. 2). The groups of people who are especially at risk were the same as today, but the proportion of people at risk of poverty or being marginalised was, according to the data of Statistik Austria and AWO-ISS, significantly higher. 27\% of adolescents under 20 years old in Austria were at risk of poverty (see Paus-Hasebrink \& Bichler, 2008, pp. 18-19). A broad overview of the development of "persistent poverty rates" between 2008 and 2011 is provided by Jenkins and Van Kerm (2017, p. 401). 


\subsection{Inequality and Mediatization}

The above findings on social disadvantage, inequality, and child poverty in rich countries become particularly important when we think of our rapidly changing world. We describe it by popularly using terms such as globalisation, individualisation, digitalisation or information society (see Castells, 2011; van Dijk, 2012).

\subsubsection{The Concept of Mediatization}

All these concepts are based on knowledge, communication, exchange and participation, and they refer to a transformation process where technological innovations, changing lifestyles, new work and life patterns, as well as emerging needs, are inextricably linked (Carpentier, Schrøder, \& Hallett, 2014). In communication and media studies, this fundamental change is primarily discussed as the "meta process" of mediatization (Krotz, 2014, p. 137, emphasis in original), which is itself "a concept with which to grasp media and societal change" (Krotz, 2009, p. 21). Mediatization refers "to the meta process by which everyday practices and social relations are increasingly shaped by mediating technologies and media organizations" (Livingstone, 2009, p. 3). Even beyond ongoing discussions regarding the correct term, "mediatization or mediation" (Couldry, 2008, p. 373), or "Mediatisierung (mediatization) and Medialisierung (medialisation)" (Livingstone, 2009, p. 3; see also Couldry \& Hepp, 2013), the concept of mediatization itself, its outreach and its relevance to the field are matter of debate (Lunt \& Livingstone, 2016, p. 462). The discussion is moving between two antipodes: For one thing, Deacon and Stanyer (2014, p. 1032) argue that mediatization is at risk to become a "concept of no difference". Furthermore, they (Deacon \& Stanyer, 2015, p. 655) voice their criticisms, because they see "the rise of a concept that claims to provide 'holistic' theoretical framework for explaining and analysing such processes" as the fundamental change of media, institutions, technologies and society. Otherwise, Hepp, Hjarvard, and Lundby (2015, p. 314) highlight "how mediatization research engages with the complex relationship between changes in media and communication, on the one hand, and changes in various fields of culture and society on the other". Hence, they see "the concept of mediatization" as a "part of a paradigmatic shift within media and communication research" (Hepp et al., 2015, p. 314). 
Regardless of the discussion about the term and critical voices, the concept of mediatization is widely accepted and within the past ten years, the observable phenomena that are interpreted as indicators of mediatization have become more intense and ubiquitous and have gained speed (see Hepp \& Hasebrink, 2018, p. 17). It has become increasingly difficult in our society to preserve media-free times and places, locations Hepp and Hasebrink (2018, p. 18) term "temporary oases of de-mediatization".

What does this intensified process of mediatization mean to children and young people? How do they make use of the abundance of media? In this respect, we can identify some global trends (see Hasebrink \& Paus-Hasebrink, 2013), which are shaped by the changing media environment. Empirical evidence regarding these trends is provided by national studies on children's and adolescents' media use in different countries-for example, the Ofcom Children and Parents Report in the United Kingdom (Ofcom, 2017) or several studies from the United States (Common Sense Media, 2015, 2016, 2017; Rideout, Foehr, \& Roberts, 2010). Similarly, for Upper Austria we can refer to a series of annual surveys on children's and adolescents' media usage (most recently, Education Group, 2016, 2017). The main studies for Germany are JIM (Youth, Information and [Multi-]Media) and KIM (Childhood, Internet, Media) (most recently, MPFS, 2016, 2017). In what follows we will outline some of the most important global trends. After that, we will illustrate recent developments through selected statistics for Austria or Germany. We take the data from these two countries as illustrating the general media-related context, in which the socially disadvantaged children and adolescents of our study grew up.

\subsubsection{Availability of Media Services}

Our premise maintains that children's and adolescents' everyday lives are particularly affected by the meta-process of mediatization. An increasing number of media devices, in a child's own bedroom and elsewhere in the family's household, the expanding range of functions offered by new services, the continuous and omnipresent availability of services which overcome temporal and spatial limits-these aspects mark a significant trend in children's and adolescents' media use. Today's children and young people have far more options for communicating than any generation before them (Rideout, 2016, p. 138). The media content and media services available to them are indeed potentially omnipresent. 


\subsubsection{Amount of Media Use}

One consequence of the omnipresence of media services seems to be that children continue to spend more and more time with media. For example, in 2009 the 8- to 18-year-olds in the United States spent more than 7.5 hours per day with media (Rideout et al., 2010, p. 11); this was more than one hour longer than five years earlier. Over those years, the proportion of multitasking increased, indicating that young people increasingly use two or even more media simultaneously, so that the total time of media exposure added up to 10.75 hours, some 2.25 hours more than five years earlier.

\subsubsection{Cross-Media Patterns of Usage}

The media industry is increasingly developing cross-media strategies, with the goal of distributing content on as many platforms as possible. Famous media brands for children may originate from games, movies, television, comics, or even books (for example, Harry Potter), but are now available almost everywhere, as the same content is now marketed across different media platforms. Such media brands represent the elements integrating and characterising children's and adolescent's media repertoires (see Paus-Hasebrink \& Hasebrink, 2015).

\subsubsection{Mobility and Connectivity of Media Usage}

Connectivity is increasingly moving away from the desktop and towards the mobile and wireless environments (see Horrigan, 2009). The Pew Report from 2010 declares: "cell phones are nearly ubiquitous in the lives of teens" (Lenhart, Purcell, Smith, \& Zickuhr, 2010, p. 9). Today, most children and adolescents use smartphones to remain almost permanently connected in some way-be it communicating with friends and peers, be it playing online computer games or just ensuring that they are constantly contactable.

While our study focuses on socially disadvantaged children and adolescents, we will illustrate some of these trends by citing some general findings on the media usage of children and adolescents in Austria and Germany.

Already in 2005, when our study started, almost all adolescents in Austria and Germany used the internet at least occasionally. In this respect, the indicator age is the most relevant factor. Our Fig. 2.1 is based on the KIM survey in Germany and shows that throughout the years of our study the difference between age groups remained stable, with most children starting to use the internet between seven and twelve years. 


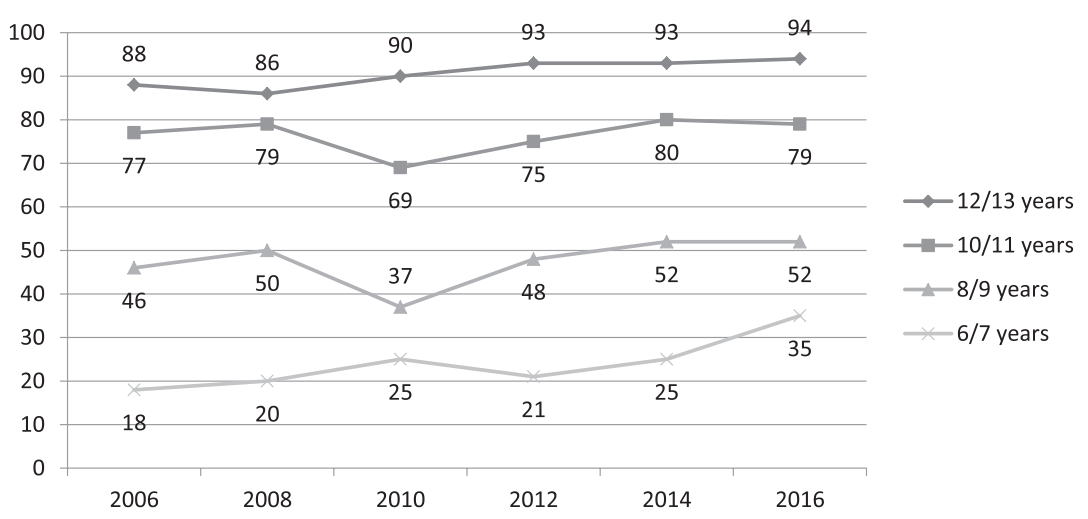

Fig. 2.1 Children (6-13 years) in Germany who use the internet (at least occasionally) (percentages; $n=1200$ ) (Source KIM 2006-2016; www.mpfs.de)

The main driver of dynamic change in children's and adolescents' media environment has been the rapid spread of smartphones. Figure 2.2 illustrates how many adolescents (12-19 years) in Germany owned a cell phone or smartphone. It took less than five years for nine out of ten adolescents to be identified as owning a smartphone. Today, almost all adolescents have their own mobile smart device. In Upper Austria, the development has been almost the same (see Education Group, 2017): smartphone ownership among adolescents between eight and 11 years in increased from $4 \%$ in 2008 to $24 \%$ in 2011 and then to $60 \%$ in 2013 , $77 \%$ in 2015 and $85 \%$ in 2017.

\subsubsection{Mediatization and Its Consequences for Socially Disadvantaged Young People}

At first glance, mediatization and social disadvantage do not seem very closely related. But the actual case is that, in general, social and material well-being is strongly connected to a high level of formal education and knowledge about media and communication. This applies particularly to digitalisation, so-called new media, automation, data processing and so on: "Information and communication technologies (ICT) have a considerable impact on living and working conditions. Nowadays, an increasing number of businesses rely on ICT for their daily operations 


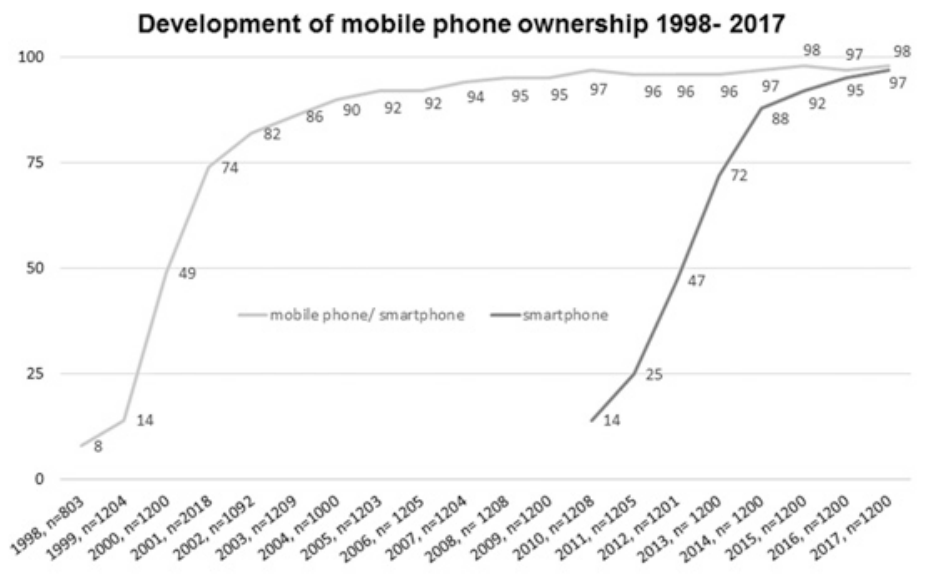

Source: JIM 1998-2017, data shown in percentages Basis: all those polled

Fig. 2.2 Cell phone and smartphone ownership among adolescents (12-19 years) in Germany (percentages) (Source JIM 1998-2017; http://www.mpfs.de)

and this often requires the development and maintenance of ICT systems by specialists" (Eurostat, 2017d, emphasis in original). As a result, unemployment rates in this sector are very low in the European Union; the employment rate for people with ICT training is 91\% (EU-28), but it rises to $97 \%$ in Germany, Hungary and Estonia and even up to $98 \%$ in Malta (Eurostat, 2017d). However, permanent employment is one of the key factors protecting individuals from poverty or social disadvantage (cf. Statistik Austria, 2017a, p. 3; Statistisches Bundesamt, 2017a; UNICEF, 2016, p. 14; van Dijk, 2013, p. 29). This example, then, shows clearly how people and their everyday lives actually are affected by processes of mediatization. The consequences of mediatization, and how to deal with them, have become huge challenges for many people all around the world (see van Dijk, 2013, pp. 29, 34). They reflect processes bringing fundamental change, and they affect virtually every human being, and two groups above all: young people and socially disadvantaged people.

Firstly, children and adolescents growing up are still searching for their identity (see Packer, 2017, pp. 477-487). They are not yet experienced in media usage and are particularly exposed to "content-related risks", "contact-related risks", and "conduct-related risks", but also 
to "other specified risks", such as for example, "health related risks", "spending too much time online" or a "lack of internet safety in general" (Livingstone, Kirwil, Ponte, \& Staksrud, with the EU Kids Online Network, 2013, p. 5) and other contract-related risks. Therefore, they need help and support from adults, in the first instance from their parents, teachers and youth workers, but also from peers, companies, organisations, the state and all other stakeholders involved (see O'Neill, Staksrud, \& McLaughlin, 2013, for a broad overview). We here emphasise one context of socialisation applying to these two groups: in mid childhood and especially adolescence, peers are of prime importance for identity formation, but also for wider questions and when practical help is needed (see Packer, 2017, pp. 487-493). But no single context of socialisation fits it all, and, in fact, the interplay of different groups succeeds best. A comparison of international surveys in 2013/14 ("Net Children Go Mobile") and in 2010 ("EU Kids Online") generated evidence that joint information and mediation strategies are helpful and "levels of digital skills are rising slowly" (Livingstone, Mascheroni, Ólafsson, \& Haddon, with the networks of EU Kids Online and Net Children Go Mobile, 2014, p. 18).

Secondly, socially disadvantaged people benefit less from the opportunities given by new possibilities for communication, information and participation, even where access is possible. "However, class is an important aspect of the structuring of inequalities, intersecting in complex ways with all inequalities" (Walby, Armstrong, \& Strid, 2012, p. 232), in particular in combination with "age" (p. 224). Today, we can benefit from the new possibilities of mass communication and from specific ways of interpersonal communication and we can participate in new fluid public spheres. But there is empirical evidence that this holds good, above all, for those with a better education, whose average income is higher and who live in urban areas with well-developed infrastructure (cf. Vorderer et al., 2015, p. 259; Wessels, 2013, p. 17). This problematic development gains in importance where the freedom of (digital) expression, the freedom of information and the freedom of access to government information and participation are considered to be universal rights for all citizens (cf. Berka \& Trappel, 2017, pp. 66-68; see also Dutton, Dopatka, Hills, Law, \& Nash, 2011, pp. 22-23; van Dijk, 2013, p. 35). Against this backdrop, the concept of a "second-level digital divide" (Hargittai, 2002) has received much attention. Its premise maintains that differences in people's online skills and access may be affected not only by 
age and experience but also by education and family income: "In particular, research in both the US and the UK has shown that children from a higher socioeconomic background are more likely to experience educational gains from home computer and internet use than others" (Hargittai \& Walejko, 2008, p. 240). We must bear in mind here that, if this applies for online media, it will take on an increased importance with traditional media as well, since people are using a broad set of different media. However, the findings on computer use and the internet cited above "are in line with work on the differentiated uses of more traditional media such as the viewing of educational television programming in earlier decades (Cook et al. 1975)" (Hargittai \& Walejko, 2008, p. 240). In addition, "access and use are the main topics of almost all the studies covered" (Paus-Hasebrink et al., 2014, p. 1), as regards online media and socially disadvantaged adolescents. "But for Europe we can state that a lack of access to the internet is not the key problem" (Berka \& Trappel, 2017, pp. 116-117; Paus-Hasebrink et al., 2014, p. 1). However, there are differences in the "quality of access" (Livingstone, Haddon, Görzig, \& Ólafsson, 201 la, p. 25): for example, mobile access, types of smartphones, data volume and speed of the connection. This equates with concerns by Jenkins, Clinton, Purushotma, Robison and Weigel, as already published in 2006 (p. 3, emphasis in original) and referring to a participation gap: "The Participation Gap-the unequal access to the opportunities, experiences, skills, and knowledge that will prepare youth for full participation in the world of tomorrow". Again, socio-economic status is highly relevant for internet usage and vice versa: "The ways in which we use the Internet, our skills and digital background, our digital and social capital, all influence our social status" (Ragnedda, 2017, p. 73). Therefore, it seems reasonable to follow Eszter Hargittai and Gina Walejko (2008, p. 239, emphasis in original) using the term "PARTICIPATION DIVIDE" instead of digital divide, and to "note that access to technology no longer wholly determines potential inequalities derived from differential information and communication technology uses" (p. 241). From research on intersectionality, we know that there might be a strengthening effect when two or more factors come together (Walby et al., 2012, p. 224). There is general agreement that all children and adolescents need our awareness, and that no less where we collect evidence for research. Furthermore, there should be more effective analysis of social disadvantage. However, we should pay special attention if these two factors coincide and we are dealing 
with socially disadvantaged children and adolescents. "Socially disadvantaged children are at risk in a double way. On the one hand, they suffer from the effects of their parents' socio-structural problems, on the other hand they use media very intensively which means that their socialisation is dominated by media" (Paus-Hasebrink et al., 2014, p. 1). Unfortunately, they are more often left alone when using media or being online and do not have the chance to ask for help or guidance. There is a high correlation between the economic well-being of a family and its educational background. The educational background of the parents has a large influence on the ways media are used in a family (see Livingstone, Haddon, Görzig, \& Ólafsson, 2011b, p. 2). Parents' formal education may be named the "key indicator of socioeconomic status" (Paus-Hasebrink, Ponte, Dürager, \& Bauwens, 2012, p. 258). However, beside socio-economic aspects as income and educational level, the socio-emotional conditions in a family also play a major role (see PausHasebrink et al., 2012; Paus-Hasebrink, 2017, p. 19). Socio-economic factors include, inter alia, a lack of financial resources or restrictions in the way of living (for example, a lack of healthy food, clothes and spare time activities, low formal education, non-prestigious jobs or bad housing situations). Socio-emotional factors are stable and trustful relationships within the family, strong ties to other important reference persons, competent contact persons in case of problems, or effective approaches to deal with problems and meet challenges. A serious problem occurs in what is termed an "Unskilled Family" (Paus-Hasebrink, Bauwens, Dürager, \& Ponte, 2013, p. 122, emphasis in original), where parents often cannot support their children and their media usage in an appropriate way. In these families, "parents have a low educational background and SES", and "the parent-child relationships are characterized by low levels of active mediation and a strong tendency to restrictive mediation" (Paus-Hasebrink et al., 2013, p. 122). At this place, active mediation refers to parents talking to their children about what they do on the internet or helping them when something is difficult to do or find on the internet. Restrictive mediation refers to parents limiting or restricting their children's internet use.

\subsubsection{Social Disadvantages and Media Experiences}

In contrast to the importance for the future of our society and of media usage and media socialisation among (socially disadvantaged) 
adolescents, studies on these topics are currently not the main field of activity in media and communication research. However, there is academic evidence on different aspects of the topics that are relevant to our research interest. In the following, we will provide a brief overview of selected studies that help us to better understand the role of media within children's socialisation, with a particular focus on socially disadvantaged children. It has to be emphasised that these studies are quite heterogeneous in how they define social disadvantaged and which particular aspect of the topic they deal with. Therefore our overview cannot provide a coherent story; instead we demonstrate the range of relevant approaches. In Chapter 3, we will present a comprehensive theoretical framework that allows for integrating the different lines of research.

To cover the field, we primarily used two sources: The European evidence database, made available by The EU Kids Online Network (2018), and the database concerning media socialisation research at https:// uni-salzburg.at/mediensozialisation (Paus-Hasebrink, von Reinersdorff, \& Sinner, 2017). In addition, a concurrent literature review was conducted. In order to cover a wide range of studies, including those with somewhat marginal topics, we followed a broad approach, using several combinations of search terms (see also Paus-Hasebrink et al., 2014, p. 8).

It is striking that a great many studies originate from Southern European countries or from such countries with greater social inequality as, for example, Brazil or Russia. Simões, Ponte, and Jorge (2013) compared people recruited in a social inclusion centre for vulnerable children and adolescents in Portugal to the results of the EU Kids Online data set. Concerning skills, they found only minor differences: for example, the socially disadvantaged adolescents had less online access at home, but they tended to use more entertainment services. A Spanish study conducted by Cabello (2013, p. 62) paid special attention to the impact of "segregated and stigmatised neighbourhoods". Based on a multi-method approach he tested their abilities to participate and deal with online media-with positive results. However, he highlighted the importance of non-family institutions to teach skills and to empower socially disadvantaged adolescents. Milioni, Doudaki, and Demertzis (2014) compared two parts of a divided country: The Republic of Cyprus/Greek-Cypriot community and Northern Cyprus/Turkish-Cypriot community. They confirm findings on the positive effect of higher education and age as regards experience and skills, but with the unexpected addition that family income is not of importance in this context in Cyprus: "In Cyprus, 
income does not appear to be related either to access, experience, and use the internet [sic!] or to specific activities online" (Milioni et al., 2014 , p. 12). In contrast, in a Dutch study already published in 2006, Peter and Valkenburg confirmed the impact of the socio-economic background, but they underlined the relevance of cognitive resources as well. Concerning aspects of the digital divide, they state: "once access gaps are bridged, other gaps open, most notably in terms of adolescents' use of the internet [...]" (Peter \& Valkenburg, 2006, p. 18). Another study on digital parenting in Russia conducted by Ravve (2012) shows both, differences between higher and lower income families in their use of technology and tremendous differences within one country relating to access and costs: "The gap between wealthy and poor parents is significant not only in terms of children's access to devices, but also in their attitudes towards technology. Higher income families tend to see a more positive impact of the digital media on kids' development" (Ravve, 2012, p. 12). Data transfer rates are high in metropolitan areas like Moscow and St. Petersburg but low in rural areas, in particular in the Eastern parts of the country, but the relation is reversed when it comes to the costs (Ravve, 2012, pp. 5, 21). These findings underline the importance of (digital) infrastructure also in more rural areas or such parts of a country that do not belong to the central or capital area in order to provide an equal standard of living. This becomes even more evident when we have a look to South America: One rapidly developing country, and member of the BRICS-states, is Brazil. However, its infrastructure and economic indicators are not yet comparable with the industrialised countries of Western Europe. A comparison of the ICT Kids Online Brazil 2012 data (Barbosa \& cgi.br, 2013) with the EU Kids Online data set reveals that the area where people live and their socio-economic status both have a great influence on their access to and use of ICTs in Brazil: "Internet access for the lowest socio-economic households was 6\%, while it was $97 \%$ for the highest" (Barbosa, O'Neill, Ponte, Simões, \& Jereissati, 2013, p. 6). In contrast, three studies from Italy and Turkey underline the important role of usage: Marco Gui (2013) compared high school students $(n=3634$, aged $15-18)$ and teachers $(n=980)$ in Lombardy and Trentino, two rich regions in the Northern part of the country (see also Gui, Micheli, \& Tamanini, 2015). The positive impact of the parents' educational and socio-economic background on three aspects stood out: the digital literacy of the children, the use of privacy setting on social networking sites by the children, the choice of personal 
information to be published on social networking sites. As far as risks and opportunities go, a Turkish study conducted by Akbulut, Sahin, and Eristi (2010) is very interesting. 1470 representatively chosen teenagers (aged 15-18) were interviewed about their online experiences and about victimisation through cyber-bullying: "The victimization scores of the high-income group were significantly higher than those of the middle-income group, whereas the low-income group was in between and did not differ from other groups significantly" (Akbulut et al., 2010, p. 199). This could not be explained by their increased internet usage of the high-income group, but by their making more frequent use of foreign websites. Children with a higher socio-economic background were also at more risk in another study, also conducted in Turkey, on internet addiction (Batigün, Kiliç, Akün, \& Özgür, 2010). In the United States, the study, "Ownership and use of new media" (Lauricella, Cingel, Blackwell, Wartella, \& Conway, 2014) was conducted among 8- to 17-year-old children and adolescents nation-wide. It covered different internet devices, mobile devices and other forms of newer media technologies in order to analyse the motivation and the ways of usage of the different age groups. The authors are able to demonstrate the diffusion of new mobile devices even among younger children and they point out that they are avid to make use of them. Furthermore, they prove the different functions of internet usage among children and adolescents of different age groups, reflecting their interests and motivations. Another nationally representative study from the United States, "Opportunity for all?" (Rideout \& Katz, 2016), is providing a special focus on lower-income families with children attending primary and secondary schools. It reported problems with slow internet connections, which is comparable to Russia or Brazil, and connections turned off due to unpaid bills. Mobile devices like smartphones and tablets are considered substitutes, but they are not suitable when it comes to more complex tasks and acquiring digital skills.

The next study has a similar orientation but with a more lifeworld oriented focus: The qualitative study conducted in Austria pays attention to poor children and adolescents ( $8-15$ years) and sets out their own perspective on poverty and their living conditions compared to other young people, who may be at risk of becoming poor, or to others who do not qualify as poor (Einböck et al., 2015). The subjects report on different access to activities and locations in their leisure time (for example, outdoor activities, sport clubs, youth centres, music schools) 
(Einböck et al., 2015, pp. 15-16). The poor children and adolescents report feeling embarrassed, because their parents are not able to support them with money, and furthermore, some of them report becoming victims of bullying due to their poverty (Einböck et al., 2015, p. 5). More detailed, cyberbullying is the specific topic of a German study from 2015 (Stodt, Wegmann, \& Brand, 2015), in connection with internet addiction and online skills. It should be emphasised that this study is not dealing with social disadvantage in general, but the authors present highly relevant characteristics and functional mechanisms that are related to the usage of internet and social networking sites as well as to internet addiction and victimisation due to cyberbullying. Particularly introverted and shy persons tend to use internet and social networking sites more intensively. The authors assume that this might be connected to a higher risk for uncontrolled usage. A high level of involvement (active, engaged and creative participation online) is likewise a predictor for being at risk of becoming internet-addicted. When it comes to cyber-bullying, victims tend to more often report timidity, depression and uncertainty in dealing with social contact. These topics are related to a study conducted by Marjon Schols (2015) in the Netherlands that deals with the results of everyday internet usage among 12- to 18-year-old teenagers: intensive usage is able to foster cohesion within peer groups. Being actively online on platforms on the internet is also a starting point for political participation online and offline. However, this study also strongly suggests that an adolescent's higher level of formal education is pointing to a more probable interest in cultural and political activities. In Norway, the digital divide and information literacy among pupils was the topic of a study by Ole Edvard Hatlevik and Greta Björk Gudmundsdottir (2013). They interviewed 3727 pupils at 50 different middle schools characterised by a multi-ethnic student body and relatively high rates of pupils with a migration background. New information and communication technologies were considered as well as "spoken language", "the number of books at home" and the young people's academic aspiration. Their "findings indicate that the number of books at home, the language spoken at home and the students' academic aspirations explain a very large proportion of the variation in information literacy between schools, and a considerable part of the variation between students-within-schools".

In all the studies discussed above, only one country is covered (or rather two communities of a divided country in the case of Cyprus). Such national research is important, but it is equally important to pay 
special attention to groups of countries for comparison purposes. Since 2006, this has been the aim of the EU Kids Online research dealing with 21 , and subsequently 33, countries in Europe (plus affiliated projects in additional countries). In order to better understand how the context of particular countries shapes the situation of children and adolescents, The EU Kids Online Network (2014, p. 8) has proposed five dimensions of country-specific characteristics, based on its work over eight years: "socio-economic stratification", "regulatory framework", "technological infrastructure", "education system" and "cultural values". In the context

of poverty and social disadvantage, the economic situation (for example, economic growth, labour market, unemployment rates), the concept of statehood (for example, political system, social system, responsibilities) and the social fabric (for example, harmonious life together, social gap, rate of inequality, integration of refugees and migrants) are of prime importance: "Countries differ heavily in terms of income, education, social welfare and other factors, leading to different perceptions of what counts as being socially disadvantaged between, and even within, countries and regions" (Paus-Hasebrink et al., 2014, p. 8).

\subsection{Conclusion}

(Child) poverty and social disadvantage are not only problems of so-called poor countries but also of rich Western societies like Austria and Germany. Social disadvantage is in most cases strongly connected to lower formal education and worse future prospects. This goes handin-hand with a lack of participation opportunities within society. As regards processes of technological and societal change-framed as the meta-process of mediatization-we have to consider that socially disadvantaged people, in particular children and adolescents, are at risk of falling further and further behind. Therefore, we need to investigate how socially disadvantaged children and adolescents grow up in their specific life situation.

As has been shown in the literature review, the majority of the respective studies deals with differences between socially disadvantaged and non-disadvantaged adolescents in terms of internet access, usage and skills. Only a few of them take a closer look into the particular situation of children and adolescents who grow up in socially disadvantaged contexts. From our own research on the role of media for socially disadvantaged children and young people, we draw the following conclusions. 
Firstly, mediatization is closely linked to what we call cross-media. Therefore, we have to ensure we not only pay attention to single media usage but also to "cross-media practices" (Hasebrink \& Hepp, 2017 , p. 362). In a mediatised cross-media society, doing single-media research, such as, for example, television research, radio research or online research, falls short. We need an integrative approach which allows us to answer the questions as to which media services are used by young people, how they are combined and why young people make use of them (see Vorderer et al., 2015, pp. 272-274). With the concept of "media repertoires", Uwe Hasebrink and Jutta Popp (2006) introduce an idea into the debate on how audience studies might capture people's use of various media. Media repertoires reflect "patterns of behaviour" and "meaningful practices" (Hasebrink \& Dohmeyer, 2012, p. 757). Such an approach is able to breathe life into the concept of cross-media because it pays the same attention to more traditional media, like TV, radio, books and newspapers, as it does to online media or new communication tools.

Secondly, we have to focus on children and adolescents within the context of their lifeworld and their social environment. The central question in this respect is how young people make subjective sense of media in general and of the specific kinds of content and services they use in order to deal with their everyday challenges. We need to reflect the interplay between socio-economic and socio-emotional aspects of socialisation and to carefully look at children's and young people's opportunities within their socialisation, which are narrowly connected to the social situation where they grow up. Against this background, the research question of our study is: How do socially disadvantaged life circumstances affect adolescents, their socialisation and their opportunities to participate in society and which role do media play in this context?

In order to answer this question, we developed a theoretical and methodological approach which will be presented in Chapters 3 and 4. As we set out to gain a deeper insight into children's livesembedded in their families and the families' social situation-we decided to conduct a qualitative long-term study with a panel of socially disadvantaged children and families, extending from 2005, when children were five years old, until 2017, when they were on the edge of adulthood. 


\section{REFERENCES}

Akbulut, Y., Sahin, Y. L., \& Eristi, B. (2010). Cyberbullying victimization among Turkish online social utility members. Educational Technology \& Society, 13(4), 192-201.

Atkinson, A. B., Guio, A.-C., \& Marlier, E. (2017). Monitoring social inclusion in Europe. In A. B. Atkinson, A.-C. Guio, \& E. Marlier (Eds.), Monitoring social inclusion in Europe-2017 edition (pp. 33-49). City of Luxembourg, Luxembourg: Publications Office of the European Union. Retrieved from http://ec.europa.eu/eurostat/documents/3217494/8031566/KS-05-14075-EN-N.pdf/c3a33007-6cf2-4d86-9b9e-d39fd3e5420c.

AWO-ISS. (2012). "Von alleine wächst sich nichts aus..." Lebenslagen von armen Kindern und Jugendlichen und gesellschaftliches Handeln bis zum Ende der Sekundarstufe I. Abschlussbericht der 4. Phase der Langzeitstudie im Auftrag des Bundesverbandes der Arbeiterwohlfahrt. Auszug [Living conditions of poor children and adolescents and social action]. Frankfurt am Main, Germany: AWO. Retrieved from http://www.awo-frankfurt.com/fileadmin/user upload/dokumente/Sozial_und_Politisch/Armut/AWO-ISS-Armutsstudie_ zentrale_Ergebnisse.pdf.

AWO-ISS. (2013). Lebenslagen und Zukunftschancen von (armen) Kindern und Jugendlichen in Deutschland. 15 Jahre AWO-ISS-Studie [Living conditions and future perspectives of (poor) children and adolescents in Germany]. Frankfurt am Main and Berlin, Germany: Institut für Sozialarbeit und Sozialpädagogik e.V. \& AWO Bundesverband. Retrieved from http://www.iss-ffm.de/m_l06.

Barbosa, A., \& cgi.br. (2013). ICT Kids Online Brazil 2012: Survey on internet use by children in Brazil. São Paulo: Comitê Gestor da Internet no Brasil. São Paulo, Brazil: cgi.br. Retrieved from http://cetic.br/media/docs/publicacoes $/ 2$ /tic-kids-online-2012.pdf.

Barbosa, A., O’Neill, B., Ponte, C., Simões, J. A., \& Jereissati, T. (2013). Risks and safety on the internet: Comparing Brazilian and European children. The EU Kids Online Network. London, UK: LSE. Retrieved from http://eprints. lse.ac.uk $/ 54801 /$.

Batigün, A. D., Kiliç, N., Akün, E., \& Özgür, P. (2010). Internet addiction: An investigation of personality traits, psychological symptoms, social support and the aspect of related socio-demographic variables. TÜBITAK Project. Ankara, Turkey: University of Ankara.

Berka, W., \& Trappel, J. (2017). Internetfreiheit in Österreich. Eine Bestandsaufnabme auf der Grundlage der Empfehlung CM/REC(2016)5 des Ministerkomitees des Europarats an die Mitgliedstaaten zur Internetfreiheit [Internet freedom in Austria]. Salzburg, Austria: Fachbereich Öffentliches Recht/ Verfassungs- und Verwaltungsrecht \& Fachbereich Kommunikationswissenschaft der Universität Salzburg. 
Bertelsmann Stiftung. (2016). Kinderarmut. Kinder im SGB-II-Bezug in Deutschland [Child poverty in Germany]. Gütersloh, Germany: Bertelsmann Stiftung. Retrieved from https://www.bertelsmann-stiftung.de/de/themen/aktuelle-meldungen/2016/september/ kinderarmut-in-deutschland-waechst-weiter-mit-folgen-fuers-ganze-leben/.

Cabello, P. (2013). A qualitative approach to the use of ICTs and its risks among socially disadvantaged early adolescents and adolescents in Madrid, Spain. Communications, 38(1), 61-83.

Caritas. (2016). Familienarmut im Land Salzburg. Fakten. Lebenslagen. Wabrnehmungen. 2016 [Poverty of families in Salzburg]. Salzburg, Austria: Erzdiözese Salzburg. Retrieved from https://www.caritas-salzburg.at/fileadmin/storage/salzburg/webseite/aktuell/Kampagnen/ ArmutvonFamilieninSalzburgENDFASSUNG.pdf.

Carpentier, N., Schrøder, K. C., \& Hallett, L. (2014). Audience/society transformations. In N. Carpentier, K. C. Schrøder, \& L. Hallett (Eds.), Audience transformations: Shifting audience positions in late modernity (pp. 1-12). New York, NY: Routledge.

Castells, M. (2011). The rise of the network society: Second edition, with a new preface. The information age: Economy, society and culture (Vol. 1). Hoboken, NJ and Oxford, UK: Wiley-Blackwell.

Common Sense Media. (2015). Census media use by tweens and teens. San Francisco, CA: Common Sense Media. Retrieved from https://www.commonsensemedia.org/research/the-common-sense-census-media-use-by-tweensand-teens.

Common Sense Media. (2016). Census plugged-in parents of tweens and teens 2016. San Francisco, CA: Common Sense Media. Retrieved from https:// www.commonsensemedia.org/research/the-common-sense-census-pluggedin-parents-of-tweens-and-teens-2016.

Common Sense Media. (2017). Census media use by kids age zero to eight 2017. San Francisco, CA: Common Sense Media. Retrieved from https://www.commonsensemedia.org/research/the-common-sense-census-media-use-by-kidsage-zero-to-eight-2017.

Cook, T. D., Appleton, H., Conner, R. F., Shaffer, A., Tamkin, G., \& Weber, S. J. (1975). 'Sesame street' revisited. New York, NY: Russell Sage Foundation.

Couldry, N. (2008). Mediatization or mediation? Alternative understandings of the emergent space of digital storytelling. New Media \& Society, 10(3), 373-391.

Couldry, N., \& Hepp, A. (2013). Conceptualizing mediatization: Contexts, traditions, arguments. Journal of Communication Theory, 23(3), 191-202.

Deacon, D., \& Stanyer, J. (2014). Mediatization: Key concept or conceptual bandwagon? Media, Culture and Society, 36(7), 1032-1044. 
Deacon, D., \& Stanyer, J. (2015). 'Mediatization and' or 'mediatization of'? A response to Hepp et al. Media, Culture and Society, 37(4), 655-657.

Dutton, W. H., Dopatka, A., Hills, M., Law, G., \& Nash, V. (2011). Freedom of connection, freedom of expression: The changing legal and regulatory ecology shaping the internet. A report prepared for UNESCO's division for freedom of expression, democracy and peace. Paris, France: United Nations Educational, Scientific and Cultural Organization and Oxford Internet Institute. Retrieved from http://unesdoc.unesco.org/images/0019/001915/191594e.pdf.

Education Group. (2016). 5. Oö. Kinder-Medien-Studie 2016. Das Medienverbalten der 3-bis 10-Jäbrigen [Children and media in upper Austria]. Linz, Austria: Education Group.

Education Group. (2017). 5. Oö. Jugend-Medien-Studie 2017. Das Medienverbalten der 11-bis 18-Jährigen [Youth and media in upper Austria]. Linz, Austria: Education Group.

Einböck, M., Proyer, M., \& Fenninger, E. (2015). Lebensbedingungen und Sichtweisen von Kindern und Jugendlichen in und über Armut. Ergebnisse aus einer Erhebung zu den Lebenswelten und Netzwerken armutsbetroffener, armutsgefährdeter und nicht-armutsgefährdeter Kinder und Jugendlicher in zwei österreichischen Regionen [Living conditions and perspectives of children and adolescents in poverty, at risk to poverty and not at risk to poverty in two regions of Austria]. Projektberichte der Volkshilfe Österreich. Wien, Austria: Volkshilfe. Retrieved from https://www.volkshilfe.at/cms/download.php?downloadId=348\&language $I d=1$.

Eurostat. (2017a). Key figures on Europe-2017 edition. City of Luxembourg, Luxembourg: Publications Office of the European Union. Retrieved from http://ec.europa.eu/eurostat/documents/3217494/8309812/KS-EI-17001-EN-N.pdf/b7df53f5-4faf-48a6-acal-c650d40c9239.

Eurostat. (2017b). 17 October: International day for the eradication of poverty. Downward trend in the share of persons at risk of poverty or social exclusion in the EU. But still over 115 million people in this situation. City of Luxembourg, Luxembourg: Publications Office of the European Union. Retrieved from http://ec.europa.eu/eurostat/documents/2995521/8314163/3-16102017 -BP-EN.pdf/d31 fadc6-a284-47f3-aelc-8212a581b0cl.

Eurostat. (2017c). Eurostatistics. Data for short-term economic analysis—09/2017. City of Luxembourg, Luxembourg: Publications Office of the European Union. Retrieved from http://ec.europa.eu/eurostat/documents/3217494/8220902/ KS - B J - 17 - 009 - EN-N.pdf/8972 d c cb- 9 c $04-4443$ - 85 a 4 - d 0254 a8eb31c.

Eurostat. (2017d). Digital economy os society in the EU. A browse through our online world in figures -2017 edition. Profile of the digital society o businesses. 1.3 Digital skills for a digital world. City of Luxembourg, Luxembourg: 
Publications Office of the European Union. Retrieved from http://ec.europa.eu/eurostat/cache/infographs/ict/bloc-lc.html.

Gui, M. (Ed.). (2013). Indagine sull'uso dei nuovi media tra gli studenti delle scuole superiori lombarde [New media among high school students in Lombardia]. Dipartimento di Sociologia e Ricerca Sociale - Università di Milano-Bicocca. Milano, Italy: Regione Lombardia. Retrieved from http:// www.orientainsieme.it/wp-content/uploads/2014/10/Indagine-uso-deimedia-studenti-Lombardia.pdf.

Gui, M., Micheli, M., \& Tamanini, C. (2015). I media digitali nella vita dei sedicenni delle scuole del Trentino: usi e competenze [Digital media in the lives of the 16 years olds in schools of Trentino: Use and competencies]. Istituto provinciale per la ricerca e la sperimentazione educativa. Rovereto, Italy: IPRASE. Retrieved from http://community.formazionescuolatrentina.it/j/ file_iprase/attachs/292.pdf.

Guio, A.-C., Gordon, D., \& Marlier, E. (2017). Measuring child material deprivation in the EU. In A. B. Atkinson, A.-C. Guio, \& E. Marlier (Eds.), Monitoring social inclusion in Europe-2017 edition (pp. 209-224). City of Luxembourg, Luxembourg: Publications Office of the European Union. Retrieved from http://ec.europa.eu/eurostat/documents/3217494/8031566/KS-05-14075-EN-N.pdf/c3a33007-6cf2-4d86-9b9e-d39fd3e5420c.

Hargittai, E. (2002). Second-level digital divide: Differences in people's online skills. First Monday, 7(4). Retrieved from http://firstmonday.org/article/ view $/ 942 / 864$.

Hargittai, E., \& Walejko, G. (2008). The participation divide: Content creation and sharing in the digital age. Information, Community and Society, 11(2), 239-256.

Hasebrink, U., \& Domeyer, H. (2012). Media repertoires as patterns of behaviour and as meaningful practices: A multimethod approach to media use in converging media environments. Participations: Journal of Audience of Reception Studies, 9(2), 757-783.

Hasebrink, U., \& Hepp, A. (2017). How to research cross-media practices? Investigating media repertoires and media ensembles. Convergence: The International Journal of Research into New Media Technologies, 23(4), 362-377.

Hasebrink, U., \& Paus-Hasebrink, I. (2013). Trends in children's consumption of media. In D. Lemish (Ed.), The Routledge international handbook of children, adolescents and media (pp. 31-38). Milton Park and London, UK: Routledge and Taylor \& Francis.

Hasebrink, U., \& Popp, J. (2006). Media repertoires as a result of selective media use: A conceptual approach to the analysis of patterns of exposure. Communications, 31(2), 369-387.

Hatlevik, O. E., \& Gudmundsdottir, G. B. (2013). An emerging digital divide in urban school children's digital literacy: Challenging equity in the Norwegian 
school system. First Monday, 18. Retrieved from http://firstmonday.org/ojs/ index.php/fm/article/view/4232/364l\#author.

Hepp, A., \& Hasebrink, U. (2018). Researching transforming communications in times of deep mediatization: A figurational approach. In A. Hepp, A. Breiter, \& U. Hasebrink (Eds.), Communicative figurations: Transforming communications in times of deep mediatization (pp. 15-48). London, UK: Palgrave Macmillan.

Hepp, A., Hjarvard, S., \& Lundby, K. (2015). Mediatization: Theorizing the interplay between media, culture and society. Media, Culture and Society, $37(2), 314-324$.

Horrigan, J. B. (2009). Wireless internet use. Washington, DC: Pew Report Center. Retrieved from http://www.pewinternet.org/2009/07/22/ wireless-internet-use/.

Jenkins, H., Clinton, K., Purushotma, R., Robison, A. J., \& Weigel, M. (2006). Confronting the challenges of participatory culture: Media education for the 21st century. An occasional paper on digital media and learning. Chicago, IL: The John D. and Catherine T. MacArthur Foundation. Retrieved from https:// www.curriculum.org/secretariat/files/Sept30TLConfronting.pdf.

Jenkins, S. P., \& Van Kerm, P. (2017). How does attrition affect estimates of persistent poverty rates? The case of EU-SILC. In A. B. Atkinson, A.-C. Guio, \& E. Marlier (Eds.), Monitoring social inclusion in Europe-2017 edition (pp. 400-417). City of Luxembourg, Luxembourg: Publications Office of the European Union. Retrieved from http://ec.europa.eu/ eurostat/documents/3217494/8031566/KS-05-14-075-EN-N.pdf/ c3a33007-6cf2-4d86-9b9e-d39fd3e5420c.

Jokinen, K., \& Kuronen, M. (2011). Research on families and family policies in Europe: Major trends. In U. Uhlendorff, M. Rupp, \& M. Euteneuer (Eds.), Wellbeing of families in future Europe: Challenges for research and policy (pp. 13-118). Dortmund, Germany: Familyplatform. Retrieved from https://eldorado.tu-dortmund.de/bitstream/2003/28914/1/Wellbeing OfFamiliesInEurope.pdf.

Krotz, F. (2009). Mediatization: A concept with which to grasp media and societal change. In K. Lundby (Ed.), Mediatization: Concept, changes, consequences (pp. 21-40). New York, NY: Peter Lang.

Krotz, F. (2014). Mediatization as a mover in modernity: Social and cultural change in the context of media change. In K. Lundby (Ed.), Mediatization of communication: Handbook of communication science (pp. 131-162). Berlin, Germany: de Gruyter.

Lange, A., \& Xyländer, M. (2011). Bildungswelt Familie. Disziplinäre Perspektiven, theoretische Rahmungen und Desiderate der empirischen Forschung [Education world family: Disciplinary perspectives, theoretical frames and desideratum for research]. In A. Lange \& M. Xyländer (Eds.), Bildungswelt Familie. Theoretische Rabmung, empirische Befunde und 
disziplinäre Perspektiven [Education world family: Theoretical frame, empirical evidence and disciplinary perspectives] (pp. 23-94). Weinheim and München, Germany: Juventa.

Laubstein, C., Holz, G., \& Seddig, N. (2016). Armutsfolgen für arme Kinder und Jugendliche. Erkenntnisse aus empirischen Studien in Deutschland [Consequences of poverty for children and adolescents: Empirical evidence from research in Germany]. Gütersloh, Germany: Bertelsmann Stiftung. Retrieved from https://www.bertelsmann-stiftung.de/fileadmin/files/BSt/ Publikationen/GrauePublikationen/Studie_WB_Armutsfolgen_fuer_Kinder_ und_Jugendliche_2016.pdf.

Lauricella, A. R., Cingel, D. P., Blackwell, C., Wartella, E., \& Conway, A. (2014). The mobile generation: Youth and adolescent ownership and use of new media. Communication Research Reports, 31(4), 357-364.

Lenhart, A., Purcell, K., Smith, A., \& Zickuhr, K. (2010). Social media \& mobile internet use among teens and young adults. Washington, DC: Pew Report Center. Retrieved from http://pewinternet.org/Reports/2010/SocialMedia-and-Young-Adults.aspx.

Livingstone, S. (2009). On the mediation of everything: ICA presidential address 2008. Journal of Communication, 59(1), 1-18.

Livingstone, S., Haddon, L., Görzig, A., \& Ólafsson, K. (2011a). Risks and safety on the internet: The perspective of European children-Full findings and policy implications from the EU Kids Online survey of 9-16 year olds and their parents in 25 countries. The EU Kids Online Network. London, UK: LSE. Retrieved from http://eprints.lse.ac.uk/33731/.

Livingstone, S., Haddon, L., Görzig, A., \& Ólafsson, K. (2011b). Disadvantaged children and online risk. The EU Kids Online Network. London: LSE. Retrieved from http://eprints.lse.ac.uk/39385/.

Livingstone, S., Kirwil, L., Ponte, C., \& Staksrud, E., with the EU Kids Online Network. (2013). In their own words: What bothers children online? The EU Kids Online Network. London, UK: LSE. Retrieved from http://eprints.lse. ac.uk/48357/.

Livingstone, S., Mascheroni, G., Ólafsson, K., \& Haddon, L., with the networks of EU Kids Online and Net Children Go Mobile. (2014). Children's online risks and opportunities: Comparative findings from EU Kids Online and Net Children Go Mobile. The EU Kids Online Network. London, UK: LSE. Retrieved from http://eprints.lse.ac.uk/id/eprint/60513.

Lunt, P., \& Livingstone, S. (2016). Is 'mediatization' the new paradigm for our field? A commentary on Deacon and Stanyer $(2014,2015)$ and Hepp, Harvard, and Lundby (2015). Media, Culture and Society, 38(3), 462-470.

Milioni, D. L., Doudaki, V., \& Demertzis, N. (2014). Youth, ethnicity, and a 'reverse digital divide': A study of internet use in a divided country. Convergence: The International Journal of Research into New Media Technologies, 20(3), 316-336. 
MPFS (Medienpädagogischer Forschungsverbund Südwest). (2016). KIM 2016. Kindheit, Internet, Medien. Basisstudie zum Medienumgang 6- bis 13-Jäbriger in Deutschland [KIM 2016. Childhood, internet, media]. Stuttgart, Germany: MPFS. Retrieved from https://www.mpfs.de/fileadmin/files/ Studien/KIM/2016/KIM_2016_Web-PDF.pdf.

MPFS (Medienpädagogischer Forschungsverbund Südwest). (2017). JIM 2017. Jugend, Information, (Multi-)Media. Basisstudie zum Medienumgang 12- bis 19-Jäbriger in Deutschland [JIM 2017. Adolescents, information, (multi-) media]. Stuttgart, Germany: MPFS. Retrieved from. https://www.mpfs.de/ fileadmin/files/Studien/JIM/2017/JIM_2017.pdf.

O'Neill, B., Staksrud, E., \& Mclaughlin, S. (Eds.). (2013). Towards a better internet for children: Policy pillars, players and paradoxes. Research antologies. Gothenburg, Sweden: Nordicom.

Ofcom. (2017). Children and parents: Media use and attitudes report. London, UK: Ofcom. Retrieved from https://www.ofcom.org.uk/research-and-data/ media-literacy-research/childrens/children-parents-2017.

ORF/APA. (2017). Österreich weiter viertreichstes EU-Land [Austria remains on rank four of the richest countries of the European Union]. Wien, Austria: ORF and Austria Presse Agentur. Retrieved from http://orf.at/ stories $/ 2395280 /$.

Packer, M. J. (2017). Child development: Understanding a cultural perspective. London, UK, Los Angeles, CA, New Delhi, India, and Singapore: Sage.

Palentien, C. (2003). Armut - Subjekt - Sozialisation. Ein Plädoyer für eine Stärkung sozialisationstheoretischer Perspektiven in der aktuellen Diskussion eines sozialen Phänomens [Poverty—subject-socialisation: A plea to foster a socialisation theoretical perspective]. In J. Mansel, H. M. Griese, \& A. Scherr (Eds.), Theoriedefizite der Jugendforschung. Standortbestimmung und Perspektiven [Theory gaps in youth research: Determination and perspectives] (pp. 91-101). Weinheim and München, Germany: Juventa.

Paus-Hasebrink, I. (2017). Mediengebrauch in der Sozialisation: LangzeitPanelstudie zu sozial benachteiligten Heranwachsenden [Media usage and socialisation]. In I. Paus-Hasebrink (Ed.), Langzeitstudie zur Rolle von Medien in der Sozialisation sozial benachteiligter Heranwachsender. Lebensphase Jugend [Longitudinal study on the role of media within socialisation of socially disadvantaged adolescents: Phase of adolescence] (pp. 15-20). BadenBaden, Germany: Nomos.

Paus-Hasebrink, I., \& Bichler, M. (2008). Mediensozialisationsforschung. Theoretische Fundierung und Fallbeispiel sozial benachteiligte Kinder [Media socialisation research-Theoretical foundation and a case study on socially disadvantaged children]. Assisted by C. Wijnen. Innsbruck, Austria: Studienverlag. 
Paus-Hasebrink, I., \& Hasebrink, U. (2015). Media brands in everyday lives. In G. Siegert, K. Förster, S. Chan-Olmsted, \& M. Ots (Eds.), Handbook of media branding (pp. 295-306). Heidelberg, Germany and New York, NY: Springer International Publishing.

Paus-Hasebrink, I., \& Kulterer, J. (2014a). Praxeologische Mediensozialisationsforschung. Langzeitstudie zu sozial benachteiligten Heranwachsenden [Praxeological media socialisation research. A longitudinal study regarding socially disadvantaged adolescents]. Assisted by P. Sinner. Baden-Baden, Germany: Nomos.

Paus-Hasebrink, I., \& Kulterer, J. (2014b). Socially disadvantaged children, media and health. In C. von Feilitzen \& J. Stenersen (Eds.), Risks and rights: Young people, media and health. The International Clearinghouse on Children, Youth and Media Yearbook (pp. 33-44). Gothenburg, Sweden: Nordicom.

Paus-Hasebrink, I., Bauwens, J., Dürager, A. E., \& Ponte, C. (2013). Exploring types of parent-child relationship and internet use across Europe. Journal of Children and Media-JOCAM, 7(1), 114-132.

Paus-Hasebrink, I., Ponte, C., Dürager, A. E., \& Bauwens, J. (2012). Understanding digital inequality: The interplay between parental socialization and children's development. In S. Livingstone, L. Haddon, \& A. Görzig (Eds.), Children, risk and safety on the internet: Research and policy challenges in comparative perspective (pp. 257-271). Bristol, UK: Policy Press.

Paus-Hasebrink, I., Sinner, P., \& Prochazka, F. (2014). Children's online experiences in socially disadvantaged families: European evidence and policy recommendations. The EU Kids Online Network. London, UK: LSE. Retrieved from http://eprints.lse.ac.uk/57878/1/EU_Kids_Online_Disadvantaged_children.pdf.

Paus-Hasebrink, I., von Reinersdorff, D., \& Sinner, P. (2017). Forschungsüberblick Mediensozialisationsforschung 2017 [Literature review on research concerning media socialisation 2017]. Salzburg, Austria: Universität Salzburg. Retrieved from https://uni-salzburg.at/fileadmin/multimedia/Kommunikationswissen schaft/documents/Abteilungen/Mediensozialisation/Literaturstudie_2017/ Literaturu\%CC\%88berblick_Mediensozialisation_2017.pdf.

Peter, J., \& Valkenburg, P. M. (2006). Adolescents' internet use: Testing the "disappearing digital divide" versus the "emerging digital differentiation" approach. Poetics, 34(4-5), 293-305.

Ragnedda, M. (2017). The third digital divide: A Weberian approach to digital inequalities. London, UK and New York, NY: Routledge.

Ravve, R. (2012). Digital parenting Russia I: How Russian parents view and capitalize on digital media. Moscow: Anketki Research. Retrieved from https:// de.slideshare.net/digitalparentingrussia/dprl-en.

Rideout, V. (2016). Measuring time spent with media: The common sense census of media use by US 8- to 18-year-olds. Journal of Children and MediaJOCAM, 10(1), 138-144. 
Rideout, V., Foehr, U. G., \& Roberts, D. F. (2010). Generation M $^{2}$ : Media in the lives of 8- to 18-year-olds. A Kaiser Family Foundation study. Menlo Park, CA: The Henry J. Kaiser Family Foundation. Retrieved from https://kaiserfamilyfoundation.files.wordpress.com/2013/04/8010.pdf.

Rideout, V., \& Katz, V. S. (2016). Opportunity for all? Technology and learning in lower-income families. A report of the families and media project. New York, NY: The Joan Ganz Cooney Center at Sesame Workshop. Retrieved from http://digitalequityforlearning.org/wp-content/uploads/2015/12/ jgcc_opportunityforall.pdf.

Schols, M. (2015). Young, online and connected: The impact of everyday internet use of Dutch adolescents on social cohesion. Rotterdam, The Netherlands: Erasmus Research Centre for Media, Communication and Culture.

Simões, J. A., Ponte, C., \& Jorge, A. (2013). Online experiences of socially disadvantaged children and young people in Portugal. Communications, 38(1), 85-106.

SOS Kinderdorf. (2017). Verstärkte Maßnahmen gegen Kinderarmut. Unsere Forderung an die zukünftige Regierung, zentrale Maßnabmen gegen Kinderarmut zu setzen [Enhanced measures against child poverty: Demands on policies of the new government]. Innsbruck, Autria: SOS Kinderdorf. Retrieved from https://www.sos-kinderdorf.at/so-hilft-sos/kinderrechte/ downloads/verstarkte-ma\%C3\%9Fnahmen-gegen-kinderarmut\#.

Statistik Austria. (2017a). Statistics Brief Armut [Poverty]. Wien, Austria: Statistik Austria. Retrieved from http://www.statistik-austria.at/wcm/ idc/idcplg? IdcService=GET_PDF_FILE\&RevisionSelectionMethod= LatestReleased\&dDocName $=114988$.

Statistik Austria. (2017b). Tabellenband EU-SILC 2016. Einkommen, Armut und Lebensbedingungen [EU-SILC 2016. Income, poverty and living conditions]. Wien, Austria: Statistik Austria. Retrieved from https://www.sozialministerium.at/cms/site/attachments/7/0/0/CH3434/CMS1493709119968/ tabellenband_eu-silc_2016.pdf.

Statistisches Bundesamt. (2016). Datenreport 2016. Ein Sozialreport für die Bundesrepublik Deutschland [Data report 2016. A social report for the Federal Republic of Germany]. Bonn, Germany: Statistisches Bundesamt \& Bundeszentrale für politische Bildung. Retrieved from https://www.destatis.de/DE/Publikationen/Datenreport/Downloads/Datenreport2016. pdf?_blob=publicationFile.

Statistisches Bundesamt. (2017a). 19.7\% der Bevölkerung Deutschlands von Armut oder sozialer Ausgrenzung bedroht [19.7\% of the population in Germany are at risk of poverty or marginalisation]. Wiesbaden, Germany: Statistisches Bundesamt. Retrieved from https://www.destatis.de/DE/ PresseService/Presse/Pressemitteilungen/2017/11/PDl7_392_634.html. 
Statistisches Bundesamt. (2017b). Armutsgefährdung in den Bundesländern weiter unterschiedlich [Risk of poverty remains different in the German Länder]. Wiesbaden, Germany: Statistisches Bundesamt. Retrieved from https://www.destatis.de/DE/PresseService/Presse/ Pressemitteilungen/2017/08/PD17_298_122.html.

Stodt, B., Wegmann, E., \& Brand, M. (2015). Geschickt geklickt?! Zum Zusammenhang von Internetnutzungskompetenzen, Internetsucht und Cybermobbing bei Jugendlichen und jungen Erwachsenen [Competencies of usage, internet addiction and cyberbullying among adolescents and young adults]. Leipzig, Germany: Vistas.

The EU Kids Online Network. (2014). EU Kids Online: Findings, methods, recommendations. The EU Kids Online Network. London, UK: LSE. Retrieved from http://eprints.lse.ac.uk/id/eprint/60512.

The EU Kid Online Network. (2018). European evidence database. The EU Kids Online Network. London, UK: LSE. Retrieved from http://www.lse.ac.uk/ media@lse/research/EUKidsOnline/DB/home.aspx.

UNICEF. (2016). Fairness for children. A league table of inequality in child well-being in rich countries. Innocenti Report Card 13. Children in the Developed World. Florence, Italy: UNICEF Office of Research-Innocenti. Retrieved from https://www.unicef-irc.org/publications/pdf/RC13_eng. pdf.

van Dijk, J. A. G. M. (2012). The network society (3rd ed.). London, UK, Thousand Oaks, CA, New Delhi, India, and Singapore: Sage.

van Dijk, J. A. G. M. (2013). A theory of the digital divide. In M. Ragnedda \& G. W. Muschert (Eds.), The digital divide: The internet and social inequality in international perspective (pp. 29-52). London, UK and New York, NY: Routledge.

Vorderer, P., Klimmt, C., Rieger, D., Baumann, E., Hefner, D., \& Knop, K., ..., Wessler, H. (2015). Der mediatisierte Lebenswandel: Permanently online, permanently connected [A mediatised living]. Publizistik, 60(3) 259-276.

Walby, S., Armstrong, J., \& Strid, S. (2012). Intersectionality: Multiple inequalities in social theory. Sociology, 46(2), 224-240.

Wessels, B. (2013). The reproduction and reconfiguration of inequality: Differentiation and class, status and power in the dynamics of digital divides. In M. Ragnedda \& G. W. Muschert (Eds.), The digital divide: The internet and social inequality in international perspective (pp. 17-28). London, UK and New York, NY: Routledge. 
Open Access This chapter is licensed under the terms of the Creative Commons Attribution 4.0 International License (http://creativecommons.org/licenses/ by $/ 4.0 /$ ), which permits use, sharing, adaptation, distribution and reproduction in any medium or format, as long as you give appropriate credit to the original author(s) and the source, provide a link to the Creative Commons licence and indicate if changes were made.

The images or other third party material in this chapter are included in the chapter's Creative Commons licence, unless indicated otherwise in a credit line to the material. If material is not included in the chapter's Creative Commons licence and your intended use is not permitted by statutory regulation or exceeds the permitted use, you will need to obtain permission directly from the copyright holder.

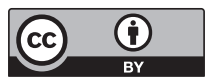

